University of Wyoming College of Law

Law Archive of Wyoming Scholarship

2-16-2018

\title{
The Dynamic Duo of Consumer Protection: State and Private Enforcement of Unfair and Deceptive Trade Practices Laws
}

Dee Pridgen

University of Wyoming College of Law, pridgen@uwyo.edu

Follow this and additional works at: https://scholarship.law.uwyo.edu/faculty_articles

\section{Recommended Citation}

Pridgen, Dee, "The Dynamic Duo of Consumer Protection: State and Private Enforcement of Unfair and Deceptive Trade Practices Laws" (2018). Faculty Articles. 13.

https://scholarship.law.uwyo.edu/faculty_articles/13

This Article is brought to you for free and open access by the UW College of Law Faculty Scholarship at Law Archive of Wyoming Scholarship. It has been accepted for inclusion in Faculty Articles by an authorized administrator of Law Archive of Wyoming Scholarship. 


\title{
THE DYNAMIC DUO OF CONSUMER PROTECTION: STATE AND PRIVATE ENFORCEMENT OF UNFAIR AND DECEPTIVE TRADE PRACTICES LAWS
}

\author{
DeE PRIDGEN*
}

State laws that protect consumers are at a crossroads. State consumer protection statutes, otherwise known as Unfair and Deceptive Acts or Practices (UDAP) laws, have been on the books of all states for some 40-plus years. They have been used by both state attorneys general and consumers. State UDAP laws were initially passed to extend consumer protection from the Federal Trade Commission to the states and to individuals. In this respect, these state UDAP laws achieve the same complementary enforcement by federal, state, and private parties that has been in place with the antitrust laws since their outset at the turn of the 20th century. ${ }^{1}$

The state UDAP laws were initially somewhat slow to be invoked, but their enforcement has now reached a level of maturity and strength that is quite impressive. Yet in some quarters, the rise of UDAP cases has been problematic. Critics have called for reforms that would in fact cripple the state UDAP law "dynamic duo": the state attorneys general enforcing the laws and consumers exercising their private right of action. This article explains the critical roles of state and private litigation under UDAP laws, even as they have changed and grown in importance in the years since the original enactments.

\footnotetext{
* The Carl M. Williams Professor of Law and Social Responsibility, University of Wyoming College of Law. The author thanks Matt Sawchak, Jeff Sovern, Mark Totten, Prentiss Cox, and Amy Widman for their comments on an earlier draft of this article. The author also thanks Gabrielle Z.A. Kohlmeier and the editors of the Antitrust Law Journal for their helpful editing suggestions.

${ }^{1}$ Clayton Act of 1914, ch. 323, 38 Stat. 730, 15 U.S.C. $§ 15$ (establishing a private right of action to enforce the antitrust laws).
}

81 Antitrust Law Journal No. 3 (2017). Copyright 2017 American Bar Association. Reproduced by permission. All rights reserved. This information or any portion thereof may not be copied or disseminated in any form or by any means or downloaded or stored in an electronic database or retrieval system without the express written consent of the American Bar Association. 


\section{STATE UDAP LAWS: THE ORIGIN STORY}

\section{A. The Model Acts}

State consumer protection statutes, known as state UDAP laws or state "little FTC acts," provide a stronghold of effective consumer protection in the United States. ${ }^{2}$ Originating during the rise of the consumer movement in the 1960s, these laws empowered both states and consumers in the fight against fraud in the marketplace. The same time period also saw a rejuvenation of the Federal Trade Commission, then the leading national consumer protection agency in the country. The FTC's leadership, instrumental in the development of the state UDAP statutes, pushed for both state and private enforcement of these new laws. The goals were to extend the reach of the FTC's consumer protection mission into the states and to provide a more productive legal tool for consumers to obtain compensation for injustices committed by unscrupulous merchants.

State consumer protection statutes banning unfair and deceptive trade practices were enacted by state legislatures in the late 1960s and early 1970s. They stemmed from three different model laws in circulation at that time, with the predominant model coming from a collaboration between the FTC and the Council of State Governments. ${ }^{3}$ The first model state law on deceptive trade practices, however, was the Uniform Deceptive Trade Practices Act promulgated in 1964 and revised in 1966 by the National Conference of Commissioners on Uniform State Laws (NCCUSL). ${ }^{4}$ This model act prohibited 11 specific deceptive practices and generally forbade "any other conduct which similarly created a likelihood of confusion or misunderstanding." ${ }^{5}$ The language of the model act suggested it was intended as a remedy for businesses damaged by unfair trade practices of competitors; it did not provide any specific powers to state government agencies. ${ }^{6}$ Private actions were limited to injunctions. This model was adopted in only 13 states, most of which also later enacted separate consumer-oriented statutes to supplement it. ${ }^{7}$

\footnotetext{
${ }^{2}$ These statutes are also referred to as "state consumer protection laws" or "state consumer protection acts."

${ }^{3}$ See generally Dee Pridgen \& Richard M. Alderman, Consumer Protection and the Law § 2:10 (West 2016-2017 ed.); Carolyn L. Carter, Nat'l Consumer Law Ctr., Unfair and Deceptive Acts and Practices $\S \S 3.4 .2 .1-3.4 .2 .5$ (9th ed. 2016).

${ }^{4}$ Uniform Deceptive Trade Practices Act (1966). This model act was withdrawn from recommendation for enactment by NCCUSL in 2000. NCCUSL, now known as the Uniform Law Commission, was established in 1892 to provide states with "non-partisan, well-conceived and well-drafted legislation that brings clarity and stability to critical areas of state statutory law." Uniform Law Comm'n, About the ULC, UnIFORMLAws.org, www.uniformlaws.org/Narrative.aspx?title $=$ About the ULC.

5 Uniform Deceptive Trade Practices Act (1966).

${ }^{6}$ See id. (Prefatory Note).

${ }^{7}$ See Pridgen \& Alderman, supra note 3.
} 
In 1971, after a number of states had already enacted unfair and deceptive practices acts, NCCUSL promulgated the Uniform Consumer Sales Practices Act (UCSPA). ${ }^{8}$ This model law was intended to "crystallize the best elements of contemporary federal and state regulation of consumer sales practices in order to effectuate harmonization and coordination of federal and state regulation." "The UCSPA was roundly criticized, however, because of its restrictive approach to consumer remedies. ${ }^{10}$ Class relief initiated by a state attorney general (AG) was limited to restitution for activities known to violate the law by being one of 11 specified practices listed in the law, or having been found to violate the act in a judicial decision or as part of a consent judgment. ${ }^{11}$ Thus, this law did not cover variations of deceptive or unfair practices that had not previously been specifically identified in the statute or in a court decision but which would nonetheless meet any reasonable standard as meriting such treatment.

Under the UCSPA, actual damages could be recovered for consumers only if they had previously complained about the practice prior to the institution of suit, something that would be unlikely to happen in the case of low-income consumers. ${ }^{12}$ Private class action remedies were also limited to previously known and statutorily specified types of violations. Class actions were subject to certain procedural requirements should the defendant offer to settle. ${ }^{13}$ For better or worse, this model law fell well short of its goal of uniformity in state consumer laws. It was ultimately enacted in only three states. ${ }^{14}$ The weakness of the remedial provisions of the UCSPA and lateness of its arrival on the scene are the likely causes of its relative unpopularity among state legislatures.

The Unfair Trade Practices and Consumer Protection Law (UTPCPL), a piece of legislation developed by the FTC in collaboration with the Council of State Governments and published in $1970,{ }^{15}$ became the prevailing model. This model contains three variations.

\footnotetext{
${ }^{8}$ Uniform Consumer Sales Practices Act (1971), Prefatory Note, reprinted in 32 CounCil of State Governments, 1973 Suggested State Legislation.

${ }^{9} \mathrm{Id}$.

${ }^{10}$ See, e.g., David A. Rice, Critique, Uniform Consumer Sales Practices Act-Damages Remedies: The NCCUSL Giveth and Taketh Away, 67 Nw. U. L. Rev. 369 (1972).

${ }^{11}$ UCSPA $\S 9$ (b).

${ }^{12}$ UCSPA $\S 9(\mathrm{a})(3)$.

${ }_{13}^{13}$ UCSPA §§ 11-13; see also The Uniform Consumer Sales Practices Act, A Panel Discussion, 27 Bus. LAw. 139-51 (1971) (discussing limits on remedies and the rationale for these limits).

14 Ohio Rev. Code Ann. § 1345.01; Kan. Stat. Ann. § 50-624; Utah Code Ann. §§ 13-111-13-11-23.

${ }^{15}$ Unfair Trade Practices and Consumer Protection Law-Revision, Prefatory Note, in CounCil of State Governments, 1970 Suggested State Legislation, Vol. XXIX [hereinafter Unfair Trade Practices and Consumer Protection Law-Revision]. The Council of State Govern-
} 
The first variation, known as the "little FTC Act," adopted by 20 states, uses the language of the federal law, and prohibits both "unfair methods of competition and unfair or deceptive acts or practices." 16 What this variation does is take the substantive language of the FTC Act and incorporates it into a piece of state legislation. Because there was no provision under the federal FTC Act for either state or private enforcement of the FTC ban on unfair or deceptive trade practices, state legislatures adopting the "little FTC Act" indirectly created a private right of action as well as state enforcement of the FTC Act.

At the time this model act was released, FTC Chairman Paul Rand Dixon stated that "cooperation between the Commission and state and local agencies is needed if the public is to be afforded adequate protection against practices which cheat consumers and unfairly injure honest businessmen." ${ }^{17}$ Dixon concluded that, as a relatively small national agency, the FTC simply did not have the resources to protect consumers effectively on the state and local level. ${ }^{18}$ The model act also contained a private right of action for injured parties to sue for recovery of their own damages, as well as losses sustained by others who had been similarly damaged, and for payment of attorneys' fees and court costs. ${ }^{19}$ Dixon applauded this aspect of the model act as well, and explained that "[o]rdinarily the amount involved in a consumer transaction is not sufficient to warrant bringing private suit, with the result that thousands of consumers suffer small losses without any remedy being available." ${ }^{20}$

The second variation, not adopted by any state, prohibited only "false, misleading, or deceptive acts or practices," and did not include "unfair" or "unconscionable" practices. ${ }^{21}$ The third variation of the UTPCPL, adopted by 26 states, used a "laundry list" approach that enumerates 12 specific prohibited practices along with a "catch-all" ban on "any act or practice which is unfair or deceptive to the consumer. ${ }^{22}$ As with the first variation, this law acts as a "little FTC Act," but with state and private enforcement.

ments is a non-partisan, non-profit organization funded by states and founded in 1933. It provides information and ideas for state legislation in its annual Suggested State Legislation, although the Council does not itself draft legislation but selects proposals to circulate. Council of State Governments, About, CSG.ORG, www.csg.org/about/default.aspx.

${ }^{16}$ See 15 U.S.C. $\S 45(\mathrm{a})(1)$ (FTC Act).

${ }^{17}$ Press Release, Fed. Trade Comm'n, FTC Urges States to Enact “Unfair Trade Practices and Consumer Protection Law" (Aug. 13, 1969) (on file with author).

${ }^{18} \mathrm{Id}$.

${ }^{19}$ Unfair Trade Practices and Consumer Protection Law-Revision, supra note 15, § 8.

${ }^{20}$ FTC Press Release, supra note 17.

${ }^{21}$ Unfair Trade Practices and Consumer Protection Law-Revision, supra note 15, § 2, Alternative Form No. 2.

${ }^{22} I d . \S 2$, Alternative Form No. 3. 
A few states did not adopt any of the model acts, but took a slightly different approach by adopting "consumer fraud acts." These acts, unlike the model act promoted by the FTC, do not include unfair methods of competition, but only prohibit deceptive or unconscionable acts or practices and consumer fraud. ${ }^{23}$ The enforcement under these consumer fraud acts by state and private actions is similar to the previously discussed model acts. Thus, all of the state UDAP laws, even those not based on one of the model statutes, essentially follow the same pattern and are discussed here as a single category.

\section{B. Original Goals of the State UDAP Laws}

The goals of the state UDAP statutes, as stated by proponents at the time of their enactment, were twofold. First, the statutes were intended to expand the protection of the consuming public as a whole from the prior practice of federal enforcement alone. This involved empowering state governments and "private attorneys general," i.e., private consumer plaintiffs. ${ }^{24}$ Second, these laws sought to provide consumers, both individually and in class actions, with direct access to adequate remedies in court for deceptive and unfair trade practices, beyond what had previously been available, i.e., inadequate common law fraud or breach of contract actions. Both the heavy burden of proof as well as the high cost of litigation associated with common law fraud and contract actions meant that the sought-after relief for consumers was often not forthcoming. The UDAP statutes both lowered the burden of proof on private consumer plaintiffs and also reduced their litigation costs by providing attorneys' fees for prevailing plaintiffs.

The first goal of extending the reach of the FTC's public consumer protection mission was accomplished in part by the state UDAP provisions that confer enforcement power on state agencies. The FTC sought to expand consumer protection to the states due to the limits on FTC jurisdiction (the FTC's authority is limited to interstate commerce), the lack of sufficient resources, and the benefits to the public that could stem from federal-state cooperation. ${ }^{25}$ The state consumer protection laws give major remedial authority to the state enforcing agencies, typically the state attorney general. Most of the state statutes provide the state AG with the authority to investigate consumer protection complaints as a civil matter, to seek injunctions in court, to accept voluntary assurances of compliance, to obtain restitution for consumers, to

\footnotetext{
${ }^{23}$ Pridgen \& Alderman, supra note 3.

${ }^{24}$ The term "private attorney general" has a continuum of meanings, but as used here, it is the concept that private lawsuits can supplement the enforcement activities of a government agency, such as the FTC or the state AG. See William B. Rubenstein, On What a "Private Attorney General" Is-and Why It Matters, 57 VAND. L. Rev. 2129, 2146-54 (2004).

${ }^{25}$ Paul Rand Dixon, Government, Consumers and Retailers: Togetherness or Conflict, 4 New ENG. L. Rev. 75, 77 (1969).
} 
obtain civil or even criminal penalties in court, and, often, to issue binding regulations. ${ }^{26}$

Massachusetts was one of the first states to adopt a UDAP statute. Initially, enforcement powers did not include a private right of action for consumers but were limited to the state attorney general. Nonetheless, the state AG's powers were sweeping, including the right to issue regulations defining unfair and deceptive practices. ${ }^{27}$ The state was also empowered to bring class actions on behalf of consumers, an authority affirmed by the state Supreme Court in a case in which the court stated: "The very purpose of the Attorney General's involvement is to provide an efficient, inexpensive, prompt and broad solution to the alleged wrong." ${ }^{28}$ Despite this legislative authority, it soon became apparent to the State AG and the Massachusetts legislature that the efforts of the state needed to be supplemented. Due to limited staff and budget, the Massachusetts AG's Consumer Protection Division was unable to handle the flood of consumer complaints they were receiving, and hence they supported the legislation that added a private right of action to the state consumer protection law. ${ }^{29}$

Thus, enlisting the forces of "private attorneys general" or private consumer plaintiffs was the next logical step in the expansion of consumer protection. By allowing consumers to enforce the state (and indirectly the federal) consumer law to redress their own individual or class injuries from unfair or deceptive trade practices, the protections derived from the federal law extended down to the individual level. As discussed in Part III, the confluence of private actions in turn benefit the public by deterring further unfair or deceptive practices.

This complementary relationship among federal, state, and private enforcement manifested in the FTC/state UDAP situation had a powerful precedent in the area of U.S. antitrust laws. The federal antitrust laws date back to the Sherman Act of 1890 and the FTC Act of $1914 .{ }^{30}$ The private right of action to enforce the antitrust laws originated in Section 4 of the Clayton Act of

\footnotetext{
${ }^{26}$ See generally PRIDGEN \& Alderman, supra note 3.

${ }^{27}$ Mass. Gen. Laws Ann. ch 93A, § 2c (discussed in Robert L. Meade, The Consumer Protection Act of Massachusetts, 4 New Eng. L. Rev. 121, 123 (1969)).

${ }^{28}$ Commonwealth v. DeCotis, 366 Mass. 234, 245, 316 N.E.2d 748, 756 (1974).

${ }^{29}$ See Slaney v. Westwood Auto, Inc., 366 Mass. 688, 698-99, 322 N.E. 2d 768, 776 (1975) (discussing the history of the Massachusetts experience with its state UDAP enforcement and the need to expand it to include private remedies).

${ }^{30}$ Sherman Act of 1890, ch. 647, 26 Stat. 209, 15 U.S.C. $\S ~ 1-7$; Federal Trade Commission Act of 1914 , ch. 311,38 Stat. 717,15 U.S.C. $\$ 45$.
} 
1914. ${ }^{31}$ But unlike in the antitrust laws, there is no direct private right of action to enforce the FTC Act. ${ }^{32}$

Thus, the state UDAP laws, by providing for private enforcement of state laws that mimic the language of the federal law, have the effect of enlisting private consumer plaintiffs in the FTC's efforts to stem unfair and deceptive trade practices..$^{33}$ Indeed, further solidifying the tie between the FTC Act and the state consumer protection laws, most of the state UDAP laws contain a provision declaring that the state legislature intended that the state courts and government enforcers be guided by relevant interpretations of the FTC Act in applying their own state law. ${ }^{34}$

The private right of action also fulfills the second goal of the UDAP statutes: to provide access for consumers to legal remedies for injuries suffered due to various unfair and deceptive practices. Prior to this statutory cause of action, consumers could in theory sue merchants for the tort of fraud or misrepresentation, for breach of contract for failure to honor a warranty, or could try to persuade the court to refuse to enforce contracts or contract clauses based on misrepresentation, fraud, or unconscionability. The burdens of proof for these common law causes of action were rather formidable, however, and included the need to show a misrepresentation of fact, not opinion, intent to deceive and justifiable reliance for tort actions, and/or convincing a court that a practice was procedurally and substantively unconscionable for contracts. ${ }^{35}$

\footnotetext{
${ }^{31}$ Clayton Act of 1914 , ch. 323, 38 Stat. 730,15 U.S.C. $\S 15$.
}

32 The text of the law contains no such provision, and the court cases have ruled out the possibility of an implied private right of action under the FTC Act. See, e.g., Holloway v. Bristol-Myers Corp., 485 F.2d 986 (D.C. Cir. 1973). Holloway remains the prevailing precedent on this point.

${ }^{33}$ See Marshall A. Leaffer \& Michael H. Lipson, Consumer Actions Against Unfair or Deceptive Acts or Practices: The Private Uses of Federal Trade Commission Jurisprudence, 48 Geo. Wash. L. Rev. 521, 553-56 (1980).

${ }^{34}$ See, e.g., Conn. Gen. STat. $§ 42-110 \mathrm{~b}(\mathrm{~b})$, which states: "It is the intent of the legislature that in construing [the prohibition of unfair methods of competition and unfair or deceptive acts or practices in the conduct of any trade or commerce], the commissioner and the courts of this state shall be guided by interpretations given by the Federal Trade Commission and the federal courts to Section 5(a)(1) of the Federal Trade Commission Act . . . ."; see also Pridgen \& Alderman, supra note 3, at app. 3B.

${ }^{35}$ The elements of the cause of action for common law fraud (also called "deceit") have been stated by Prosser and Keeton as including: false representation (not omission) of fact (not opinion) made by the defendant; knowledge or belief on the part of the defendant that the representation is false; intention to induce the plaintiff to act; justifiable reliance upon the representation on the part of the plaintiff; and resulting damage to the plaintiff from such reliance. Prosser \& KeETON ON THE LAW OF TORTS $\S 105$, at 728 (5th ed. 1984). The leading case on unconscionability in consumer contracts is Williams v. Walker-Thomas Furniture Co., 350 F.2d 445 (D.C. Cir. 1965). This classic case, involving a cross-collateral clause in a retail furniture installment contract, established that an unconscionable contract or contract clause would be unenforceable if there was "an absence of meaningful choice on the part of one of the parties together with contract terms which are unreasonably favorable to the other party." Id. at 449. 
Consumer warranty actions were often stymied by disclaimers and remedy limitations or by the holder in due course doctrine, which immunized thirdparty financers from consumer claims against sellers. ${ }^{36}$ As the Supreme Court of North Carolina stated in an early case applying that state's UDAP law, "Such legislation was needed because common law remedies had proved often ineffective. ... Against this background, and with the federal act as guidance, North Carolina and all but one of her sister states have adopted unfair and deceptive trade practices statutes." ${ }^{37}$

Most of the obstacles for consumers under the common law were indeed addressed by legislation. The FTC Act, and its state UDAP statute offspring, eliminated the need to prove intent to deceive, and justifiable reliance..$^{38}$ The restrictive common law doctrine of unconscionability is mostly replaced by the more flexible term "unfairness." 39 The state UDAPs are also illuminated by specific provisions or regulations that identify particular practices as unfair or deceptive, which may also facilitate litigation by the statutory route instead of the old common law approaches that rely on case-by-case development of doctrines.

State legislators recognized that a statutory cause of action with a more favorable burden of proof alone was not sufficient for consumers to attain vindication through legal action, however. Because of the generally low level of damages pertinent to consumer cases, other incentives were created to increase the likelihood that consumers would be able to retain professional attorney advocates for their cases. These incentives included: attorneys' fee awards for prevailing consumer plaintiffs, statutory multiple and/or minimum damage awards, and the availability of class actions. ${ }^{40}$ Most consumer goods

${ }^{36}$ Warranty disclaimers and remedy limitations on consumer products were addressed by the Magnuson-Moss Warranty Act, Pub. L. No. 93-637, Title I, 88 Stat. 2183 (1975), codified at 15 U.S.C. $\$ 2301-2312$, and the holder in due course doctrine was virtually eliminated for consumer credit transactions by an FTC rule, Preservation of Consumers' Claims and Defenses, 16 C.F.R. Part 433. For a current assessment of the effectiveness of the Magnuson-Moss Warranty Act, see Janet W. Steverson \& Aaron Munter, Then and Now: Reviving the Promise of the Magnuson-Moss Warranty Act, 63 KAn. L. Rev. 227 (2015).

${ }^{37}$ Marshall v. Miller, 302 N.C. 539, 543-44, 276 S.E.2d 397, 400 (1981).

${ }^{38}$ See, e.g., Lorenzetti v. Jolles, 120 F. Supp. 2d 181 (D. Conn. 2000) (practices may be actionable under state UDAP statute even if they are not a violation at common law); see generally CARTER, supra note 3, §§ 4.2.3.1-4.2.4.1, 4.2.12.

${ }^{39}$ Unfairness is defined by the FTC, and derivatively in the state UDAPs, as any practice that causes consumers substantial injury, whose harms outweigh its benefits, and the harms of which cannot reasonably be avoided by consumers. See FTC Policy Statement on Unfairness (Dec. 17, 1980), FTC.GOv, www.ftc.gov/public-statements/1980/12/ftc-policy-statement-unfairness (later codified at 15 U.S.C. $\S 45(\mathrm{n}))$.

${ }^{40}$ See Dee Pridgen, Wrecking Ball Disguised as Law Reform: ALEC's Model Act on Private Enforcement of Consumer Protection Statutes, 39 N.Y.U. Rev. L. \& Soc. Change 279, 288-89 (2015) [hereinafter Pridgen, Wrecking Ball] (discussing the provisions of state UDAP private rights of action aimed at supporting consumers' access to courts). 
or services are not so costly that the injury to the consumer of having been misled as to their value (purely economic loss), for instance, would justify the expense of hiring an attorney and going to court. ${ }^{41}$ As the Arizona Supreme Court stated in a breakthrough decision implying a private right of action under that state's UDAP law, "Without effective private remedies the widespread economic losses that result from deceptive trade practices remain uncompensable and a private remedy is highly desirable in order to control fraud in the marketplace." 42

Thus, the wave of state UDAP legislation that swept the nation in the late 1960s and early 1970s extended the perceived benefits of federal consumer protection law out to the states and to individual consumers by modeling state legislation on the wording of the federal FTC Act and providing concurrent state and private enforcement rights.

In the years since these laws were first enacted, the states are no longer simply junior partners of the FTC but have emerged as powerful consumer protectors in their own right. Meanwhile, the "private attorneys general," acting through both class actions and individual suits, have been very successful, so much so that class actions and even the very concept of private UDAP suits have been subject to criticism. These modern trends in the enforcement of state UDAP laws are discussed in the ensuing parts of this article.

\section{KEY ROLE OF STATE ATTORNEYS GENERAL}

As stated in the preceding part, the FTC developed their model state UDAP statute with a goal of broadening the reach of the FTC's consumer protection mission to the states. The state government enforcers were viewed as allies, perhaps even foot soldiers, in the fight against unfair and deceptive trade practices. But since the vehicle for this extension of FTC authority to the states came in the form of independently enacted state laws, the FTC had no direct control over the activities of the states in this sector, other than the federal preemption doctrine.

Over the years, the power and enthusiasm of the state AG's for their consumer protection mission grew, while the FTC and the federal government in general became less enthusiastic about perceived over-regulation of the free market during the 1980s and in later periods as well. Further venturing past their federal "parent," states also enhanced their power by joining together in multistate litigation to take on large corporate advertisers, such as the tobacco

\footnotetext{
${ }^{41}$ See David A. Rice, Remedies, Enforcement Procedures and the Duality of Consumer Transactions Problems, 48 B.U. L. Rev. 559, 569 (1968); see also Unfair Trade Practices and Consumer Protection Law-Revision, supra note 15, Prefatory Note on $\S 8$, at 4 .

${ }^{42}$ Sellinger v. Freeway Mobile Home Sales, Inc., 110 Ariz. 573, 576, 521 P.2d 1119, 1122 (1974) (en banc).
} 
companies and magazine publishers using sweepstake marketing. In the 2000s, states used their UDAP statutes to challenge prescription drug makers and predatory lenders, among others, and sometimes employed outside private counsel on a contingent fee basis to further enhance the efficiency and effectiveness of their cases.

And yet despite the periodic federal/state tensions regarding the appropriate role of government regulation in the consumer protection arena, both the FTC and the more recently created Consumer Financial Protection Bureau, continue to partner with the state AGs on so-called enforcement "sweeps." All in all, the role of the states in enforcing the state UDAPs has been beneficial for consumers and the relationship with the federal agencies has been more of a sibling rivalry than an armed conflict.

\section{A. The Evolution of State UDAP Enforcement}

The state attorneys general have an array of tools and strategies available to enforce their state UDAP laws. ${ }^{43}$ They can investigate, including through the issuance of Civil Investigative Demands, and they can settle cases, through Voluntary Assurances of Compliance. Investigation and voluntary settlements comprise the bulk of the consumer protection work of most state AGs. Litigation is expensive and time consuming for both parties. Settlements are the best way to attain results for consumers at the lowest cost to all involved.

When necessary, however, state AGs can often obtain a court injunction based on a public interest standard. ${ }^{44}$ Usually these injunctions are broad, to not only put an end to current unfair or deceptive activities but also to prevent future similar violations. Such injunctions can be quite creative and far-reaching. For instance, during the subprime mortgage crisis, the Massachusetts Attorney General obtained an injunction against a mortgage lender that prohibited the lender from initiating foreclosures without prior approval of the court on residential mortgage loans that were "presumptively unfair," based on specified underwriting criteria..$^{45}$

State attorneys general can also obtain redress or restitution for consumers either as part of injunctive relief, or as expressly authorized by the state

\footnotetext{
${ }^{43}$ See generally Prentiss Cox, Amy Widman \& Mark Totten, Strategies of Public UDAP Enforcement, HARV. J. ON LEGIS. (forthcoming 2017). This article contains an empirical descriptive study of all state UDAP cases that were finally resolved in calendar year 2014.

${ }^{44}$ In the case of state attorneys general seeking an injunction under their state UDAP statute, the standard for obtaining an injunction is usually that the state show the injunction is needed to protect the public interest. This standard is somewhat broad, but basically is left to the discretion of the courts. In any event, the state AG need not meet the standard of demonstrating the likelihood of irreparable harm that is applicable to private plaintiffs seeking injunctions. See State v. Fonk's Mobile Home Park \& Sales, Inc., 117 Wis. 2d 94, 343 N.W.2d 820, 824 (Ct. App. 1983).

${ }^{45}$ Commonwealth v. Fremont Inv. \& Loan, 452 Mass. 733, 897 N.E.2d 548 (2008).
} 
UDAP statute. This authority has been used over time in many situations, such as in a 2014 case in New Mexico, where the state attorney general obtained restitution of excessive interest and fees for customers who had purchased "signature loans" (short-term, high interest loans marketed to low income consumers). ${ }^{46}$

Civil and criminal penalties are also available in most states as a major form of deterrent for unfair and deceptive practices. Civil penalties typically go to the state treasury and are imposed if the defendant violates an existing injunction or willfully violates the statute in the case of a first violation. ${ }^{47}$ Criminal penalties, which are authorized under some state UDAP statutes, can be a very effective deterrent, but have a higher standard of proof for the state and are reserved for particularly egregious cases. ${ }^{48}$

A majority of the states have granted rulemaking authority to their state attorneys general under the state consumer protection law, although not all of them have actually issued regulations. These regulations typically have the force of law, and a violation of the regulation is a per se violation of the state statute. The value of regulations is that they can provide specific guidance to businesses seeking to comply with the rather broad mandate to avoid unfair or deceptive practices, and rulemaking authority under the state UDAP laws has been used in a variety of ways, some of which could be controversial. In Massachusetts, for example, a UDAP rule prescribes safety and quality standards for the sale of handguns in the state. ${ }^{49}$ Generally, an attorney general has broad discretion to determine whether to proceed by rule or by adjudication..$^{50}$

In the early years, the state enforcement agencies usually acted independently when choosing to litigate under their state UDAP laws. Some states,

\footnotetext{
${ }^{46}$ State ex rel. King v. B\&B Inv. Grp., Inc., 2014-NMSC-024, 329 P.3d 658. For more examples, see additional cases cited in Pridgen \& Alderman, supra note 3, § 7:13.

${ }^{47}$ Pridgen \& Alderman, supra note $3, \S 7: 18$. Some authors have suggested that certain state attorneys general are obtaining excessive civil penalties without providing businesses with adequate warning of the illegality of their activities and that the monies in some cases are going to projects and organizations that are not part of state consumer protection enforcement. See Cary Silverman \& Jonathan L. Wilson, State Attorney General Enforcement of Unfair or Deceptive Acts and Practices Laws: Emerging Concerns and Solutions, 65 Kan. L. Rev. 209, 240-56 (2016). This argument and others raised in their article will be addressed below. See infra text accompanying notes 79-102.

${ }^{48}$ See, e.g., State ex rel. Easley v. Rich Food Servs., Inc., 139 N.C. App. 691, 535 S.E.2d 84 (2000).

${ }^{49}$ State AG's authority to issue the regulations was upheld in American Shooting Sports Council, Inc. v. Attorney General, 429 Mass. 871, 711 N.E. 2d 899 (1999); see also Glenn Kaplan \& Chris Barry Smith, Patching the Holes in the Consumer Product Safety Net: Using State Unfair Practices Laws to Make Handguns and Other Consumer Goods Safer, 17 Y ALE J. ON REG. 253 (2000).

${ }^{50}$ See, e.g., Consumer Prot. Div. Office of Att'y Gen. v. Consumer Publ'g Co., 304 Md. 731, 753-55, 501 A.2d 48, 59-61 (1985); Dep't of Legal Affairs v. Father \& Son Moving \& Storage, Inc., 643 So. 2d 22 (Fla. Dist. Ct. App. 1994).
} 
such as New York, New Jersey, California, Connecticut, Massachusetts, Illinois and Texas, were leaders in aggressively enforcing their state consumer protection laws and also in pushing the boundaries of the meaning of "unfair" or "deceptive" trade practices. ${ }^{51}$ Other states, either because of limited resources or because of local political conditions, were not so active. Since the 1990s, however, many state consumer protection cases, like state antitrust cases, have taken the form of "multistate litigation." ${ }^{52}$ In these situations, multiple states in cooperation with one another, simultaneously file separate cases (or a single case if in federal court) against the same defendant using identical or equivalent legal theories under either federal or state law..$^{53}$

With multistate litigation, the resource-poor states can sign on and allow another state AG to take a leading role. Also, the multistate approach can pool whatever resources the states have into a joint effort, and achieve more clout vis-à-vis sometimes powerful and wealthy defendants, as well as spreading more restitution for consumers across more states. It can also work to the benefit of the defendants, however, to settle with all or most potential state plaintiffs at once, rather than facing piecemeal litigation. This trend toward multistate cases has been facilitated by the work of the National Association of Attorneys General (NAAG), which has established a multistate task force to coordinate such efforts in the antitrust area. ${ }^{54}$ But though NAAG also has a Consumer Protection Committee, it has no consumer protection taskforce analogous to the one for antitrust. ${ }^{55}$

Probably the best known multistate case in the consumer protection field was settled in 1998, in the Tobacco Master Settlement Agreement, in which the industry agreed to pay 46 states a total of $\$ 206$ billion over 25 years. ${ }^{56}$ While this case was actually based on a tort products liability theory, the strat-

\footnotetext{
${ }^{51}$ See J.R. Franke \& D.A. Ballam, New Applications of Consumer Protection Law: Judicial Activism or Legislative Directive?, 32 Santa Clara L. Rev. 347, 358 (1992). Some examples cited by these authors include the application of the Illinois UDAP statute to the sale of insurance despite the fact that insurance was already regulated under the Illinois Insurance Code, Fox v. Industrial Casualty Insurance Co., 424 N.E.2d 839 (Ill. Ct. App. 1981), as well as the application of the Massachusetts UDAP statute to banks, Raymer v. Bay State National Bank, 424 N.E.2d 515 (Mass. 1981).

${ }^{52}$ See Stephen Paul Mahinka \& Kathleen M. Sanzo, Multistate Antitrust and Consumer Protection Investigations: Practical Concerns, 63 Antitrust L.J. 213 (1994); see also Colin Provost, State Attorneys General, Entrepreneurship, and Consumer Protection in the New Federalism, Publius: J. Federalism, Spring 2003, at 37, 39.

${ }^{53}$ Jason Lynch, Note, Federalism, Separation of Powers, and the Role of State Attorneys General in Multistate Litigation, 101 Colum. L. Rev. 1998, 2003-04 (2001).

${ }^{54}$ Nat'l Ass'n of Att'ys General, Multistate Task Force, NAAG.org, www.naag.org/naag/ committees/naag_standing_committees/antitrust-committee/multistate_task_force.php.

${ }_{55}^{5}$ NAAG may well have a role in coordinating multistate litigation in consumer protection, but that role is not formally documented.

${ }^{56}$ The text of the settlement agreement can be accessed at www.naag.org/assets/redesign/files/ msa-tobacco/MSA.pdf. See generally James P. Nehf, The Advertising and Marketing Mandates
} 
egy used became a model for later cases filed under state UDAP statutes. Mississippi Attorney General Michael Moore was the initiator and mastermind who sought to get a critical mass of other states to sue so that the threat would be sufficiently overwhelming to bring the big tobacco companies to settlement negotiations. ${ }^{57}$ This case not only won a huge pot of money for the states and their citizens, but it also introduced the use of private counsel to represent the states collectively on a contingent fee basis. While some have criticized state delegation of cases to private counsel, a recent study concluded that the use of private counsel in state UDAP enforcement cases is relatively rare ${ }^{58}$ Nonetheless, in some instances, the use of private counsel on behalf of the state can equalize the litigation resources of the parties, since state governments (acting on behalf of consumers) are notoriously short on funds and staff, whereas many private companies have access to very expensive legal representation.

A few of many examples of large multistate consumer protection cases brought under state UDAP laws include a 1998 settlement with the national sweepstakes marketer, American Family Publishers, in a case brought by 33 state attorneys general, to curb certain specified deceptive practices. ${ }^{59}$ In 2007 , 26 states settled a case against Purdue Pharma for $\$ 19.5$ million, based on allegedly deceptive off-label marketing of OxyContin. ${ }^{60}$ Another more recent example involved a series of cases against a pharmaceutical company manufacturing a prescription drug (Risperdal) with undisclosed side effects, which was being promoted for "off-label" uses. In that case, 36 states and the District of Columbia joined in a $\$ 181$ million settlement in a case based on alleged unfair and deceptive trade practices. ${ }^{61}$ Other states filed their own

of the Attorney General Tobacco Settlement, 7 CONSUMER L.J. 281 (1999) (presenting an overview and critique of the settlement agreement).

${ }^{57}$ See Thomas A. Schmeling, Stag Hunting with the State AG: Anti-Tobacco Litigation and the Emergence of Cooperation Among State Attorneys General, 25 L. \& PoL'y 429 (2003).

${ }^{58}$ For a blistering critique of the tobacco settlement and the multistate litigation strategy, including private contingent-fee counsel, see William H. Pryor Jr., A Comparison of Abuses and Reforms of Class Actions and Multigovernment Lawsuits, 74 Tul. L. Rev. 1885, 1898-1913 (2000). For an empirical look at the actual use of private counsel in state UDAP enforcement, see Cox et al., supra note 43.

${ }^{59}$ Provost, supra note 52, at 37, 48 (tbl.). Publishers Clearing House also settled with 14 states in 1994 in a deceptive sweepstakes advertising case. Publisher's Clearing House Resolves States' Sweepstakes Solicitation Concerns, Antitrust \& Trade Reg. Rep. (BNA) No. 67, at 283 (Sept. 1, 1994).

${ }^{60}$ This case also involved a cooperative effort with federal agencies. See Ashley L. Taylor, Jr., Anthony F. Troy \& Katherine W. Tanner Smith, State Attorneys General: The Robust Use of Previously Ignored State Powers, 40 URB. LAw. 507, 513-14 (2008).

${ }^{61}$ Final Judgment and Agreed Permanent Injunction, State v. Janssen Pharm., Inc., No. 1209885 (Dallas Cty. Dist. Ct. Aug. 29, 2012) (discussed in Isaac D. Buck, Side Effects: State AntiFraud Statutes, Off-Label Marketing, and the Solvable Challenge of Causation, 36 CARdozo L. Rev. 2129 (2015)). 
individual state suits in the Risperdal controversy, alleging either a UDAP violation or fraud, with mixed results. ${ }^{62}$

\section{B. Federal/State Tensions}

Despite the state UDAP statutes' original conception as a partnership between the FTC and the states, in the 1980s and '90s some states viewed the FTC as being too lenient in the area of national advertising and thus these states stepped up their own enforcement efforts. ${ }^{63}$ These states began bringing their own cases against major national advertisers, such as Kraft, McDonald's, and Arby's. ${ }^{64}$ A study performed for the Center for Science in the Public Interest compared state cases involving national advertising with those brought by the FTC during 1991 and 1992. The study concluded that, although the states and the FTC brought roughly the same number of cases against national advertisers during the period, the states challenged bigger name advertisers and imposed larger and more frequent monetary penalties. ${ }^{65} \mathrm{In}$ a related development, spurred by the rise of potentially misleading airline price advertising, the NAAG in 1987 adopted a set of airline advertising and marketing guidelines. ${ }^{66}$ The U.S. Supreme Court ruled in 1992, however, that the 1978 federal Airline Deregulation Act preempted state regulation of airline fare advertising. ${ }^{67}$

The most recent period during which federal consumer protection actions lagged behind enforcement actions by the states was the lead-up to the financial crisis in 2008, and the ensuing Great Recession. Many consumer advocates had warned that predatory practices by subprime lenders, unchecked by any effective federal action, could result in dire consequences, such as the

${ }^{62}$ See State ex rel. Wilson v. Ortho-McNeil-Janssen Pharms., Inc., 777 S.E.2d 176 (S.C. 2015); State ex rel. McGraw v. Johnson \& Johnson, 226 W. Va. 677, 704 S.E.2d 677 (W. Va. 2010); see also Buck, supra note 61; M. Gabrielle Hils, Defending Against the Onslaught of State Attorneys General Actions Against Drug Manufacturers: Lessons Learned from Recent Cases, in Navigating Drug and Medical Device Legal Issues 95 (2014).

${ }^{63}$ See Steven J. Cole, State Enforcement Efforts Directed Against Unfair or Deceptive Practices, 56 Antitrust L.J. 125 (1987). A similar rejuvenation of state antitrust cases came in the same period as a reaction to perceived non-enforcement of the antitrust laws during the Reagan years. See Andrew I. Gavil, Reconstructing the Jurisdictional Foundation of Antitrust Federalism, 61 Geo. Wash. L. Rev. 657, 661-62 (1993).

${ }^{64}$ Texas sued Kraft for misleading advertising of Cheez Whiz as "real cheese," New York, Texas, and California investigated allegedly misleading ads for McDonald's Chicken McNuggets, and New York alleged that Arby's was misleadingly promoting a high calorie sandwich as a "lean meal." See PRIDGen \& Alderman, supra note 3, § 7:1.

${ }^{65}$ Dee Pridgen, A Comparison of Recent Federal and State Advertising Enforcement Activity (1993) (unpublished manuscript) (on file with author).

${ }^{66}$ Report and Recommendations of NAAG Task Force on Air Travel Industry, AnTITRUST \& Trade Reg. Rep. (BNA) No. 53, (Special Supp. Dec. 17, 1987).

${ }^{67}$ Morales v. Trans World Airlines, Inc., 504 U.S. 374 (1992). The U.S. Department of Transportation currently regulates the advertising of airline fares. 14 C.F.R. $399.84-399.85$. 
subprime mortgage meltdown and the resulting rise in foreclosures. ${ }^{68}$ The prevailing federal regulation of the consumer financial market at that time relied primarily on disclosures of the costs of credit as mandated by the Truth in Lending Act. Unfortunately, despite these disclosures, most consumers failed to comprehend the dangers of the toxic mortgages they had signed up for. ${ }^{69}$ Federal inaction during this period was compounded by federal preemption. State laws that were aimed at curbing predatory lending practices more directly were often preempted by federal agencies, such as the Office of Thrift Supervision and the Office of the Comptroller of the Currency. ${ }^{70}$

While the consumer protection machinery of the federal government apparently stood by for the most part, the state attorneys general, in both multistate and individual suits, challenged the unfair and deceptive practices of five of the largest subprime lenders, namely, FAMCO, Household Finance, Ameriquest, Countrywide, and Fremont Investment \& Loan. For instance, in a multilawsuit effort initiated between 1998 and 2000, the states, along with the FTC, alleged that FAMCO, a California-based nonbank mortgage lender, had used misleading sales techniques to sell subprime loans. The states, the FTC, and private plaintiffs settled with FAMCO in 2002 for $\$ 60$ million. $^{71}$ In 2002, NAAG's Subprime Lending Committee led the way, joined by all 50 states, to a major settlement with Household Finance for similar violations of state UDAPs. This settlement was for $\$ 525$ million and also included extensive injunctive measures designed to prevent future unfair mortgage terms. ${ }^{72}$ Shortly thereafter, Ameriquest, another large subprime lender, was accused in a multistate litigation of inflating appraisals and encouraging the use of fabricated or inflated income on loan applications. Ameriquest agreed to a $\$ 325$ million settlement in 2006, along with injunctive measures to prevent

\footnotetext{
${ }^{68}$ See Kathleen C. Engel \& Patricia A. McCoy, A Tale of Three Markets: The Law and Economics of Predatory Lending, 80 Tex. L. Rev. 1255 (2002).

${ }^{69}$ See Dee Pridgen, Putting Some Teeth in TILA: From Disclosure to Substantive Regulation in the Mortgage Reform and Anti-Predatory Lending Act of 2010, 24 LOYOLA Consumer L. Rev. 615 (2012); Jeff Sovern, Preventing Future Economic Crises Through Consumer Protection Law or How the Truth in Lending Act Failed the Subprime Borrowers, 71 Oнго Sт. L.J. 761 (2010).

70 See Fin. Crisis Inquiry Comm'n, The Financial Crisis Inquiry Report: Final Report of the National Commission on the Causes of the Financial and Economic Crisis in the United States 13-14 (2011), fcic-static.law.stanford.edu/cdn_media/fcic-reports/ fcic_final_report_full.pdf; see also Mark Totten, Credit Reform and the States: The Vital Role of Attorneys General After Dodd-Frank, 99 Iowa L. Rev. 115, 124 (2013); Arthur E. Wilmarth, Jr., The Dodd-Frank Act's Expansion of State Authority to Protect Consumers of Financial Services, 36 J. CoRp. L. 893, 910-15 (2011).

${ }^{71}$ Mark Totten, The Enforcers \& the Great Recession, 36 CARdozo L. Rev. 1611, 1623 (2015).

${ }^{72} I d$. at 1624 .
} 
unfair or deceptive practices in the future. ${ }^{73}$ Countrywide, another leading nonbank mortgage lender, settled with the states in $2008 .{ }^{74}$

Massachusetts AG Martha Coakley also brought an individual state case on behalf of Massachusetts against Fremont Investment and Loan. In that case, Coakley succeeded in establishing that the practice of making loans that the borrowers clearly did not have the ability to repay (i.e., loans that were doomed to fail) was unfair or deceptive under the Massachusetts UDAP statute. The state obtained injunctive relief that prohibited Fremont from foreclosing, without prior approval by the court, on loans that did not meet certain underwriting criteria. ${ }^{75}$

By 2012, when all 50 states signed off on the National Mortgage Settlement, the federal government, which had previously either been inactive or had preempted state action regarding subprime mortgage issues, was in sync with the states. By this time, there was a new administration in Washington, the Dodd-Frank Act, which included the Anti-Predatory Lending and Mortgage Reform Act, had passed, and the Consumer Financial Protection Bureau had been created. As a result, the final agreement with the major mortgage servicers was a multistate and multi-federal agency effort. ${ }^{76}$ The mortgage servicers allegedly pushed debtors into foreclosure without sufficiently reviewing other options, such as loan modification, and borrowers were plagued by poor customer service and a lack of communication with the servicing companies. ${ }^{77}$ The settlement called for loss mitigation procedures, principal reduction in some cases, refinancing for underwater mortgages, and other relief. ${ }^{78}$

Thus, state UDAP enforcement can serve as a check on federal agencies that may be "captured" by their regulatory "clients." These examples are not regulatory duplication, but instead are examples of a balancing of the federal/ state regulatory enforcement efforts on behalf of consumers.

\footnotetext{
${ }^{73} I d$. at $1625-26$.

${ }^{74} \mathrm{Id}$. at $1627-28$.

${ }^{75}$ Commonwealth v. Fremont Inv. \& Loan, 452 Mass. 733, 897 N.E.2d 548 (2008).

${ }^{76}$ Totten, supra note 71, at 1639-46.

${ }^{77}$ Press Release, U.S. Dep't of Justice, Federal Government and State Attorneys General Reach \$25 Billion Agreement with Five Largest Mortgage Servicers to Address Mortgage Loan Servicing and Foreclosure Abuses (Feb. 9, 2012), www.justice.gov/opa/pr/federal-governmentand-state-attorneys-general-reach-25-billion-agreement-five-largest.

${ }^{78}$ Id. Subsequently, in 2013 the Consumer Financial Protection Bureau (CFPB), issued a set of detailed regulations aimed at governing consumer practices in the mortgage servicing industry. 12 C.F.R. $\S \S 1024.30-1024.41$ (effective 2014).
} 


\section{Overall Assessment of State UDAP Enforcement}

The above brief sketch of the evolution of state AG enforcement of UDAP statutes raises a few questions about the implications of this evolution. ${ }^{79}$ Given the complex relationship between federal and state law in the consumer protection area, one may wonder which approach to enforcement is superior, to the extent that they may differ. The states in the course of enforcing their state UDAP statutes, at times appear to be more aggressive than the federal government, as in the national advertising cases of the 1990s or the subprime mortgage crisis of the 2000s. The states also sometimes challenge activities, such as the allegedly misleading marketing of certain drugs by pharmaceutical companies, when those activities were thought to be more appropriately regulated by federal agencies.

The ability of the states to take these different approaches while maintaining their independence from the federal law stems from the way the state UDAPs were created, i.e., as freestanding state laws based on federal policy. This unique configuration may lead to speculation as to "what is the alternative" to the version of state enforcement of the UDAP statutes that has been on the books for the past 40 to 50 years?

One alternative approach would have been for Congress to have simply provided for direct state enforcement in the FTC Act itself. Some 16 federal consumer protection laws do indeed provide for direct enforcement by the states. ${ }^{80}$ These provisions, like the state UDAP model acts, are meant to expand enforcement of a federal law by enlisting the assistance of state attorneys general. For instance, under the recently enacted Consumer Financial Protection Act (CFPA), state attorneys general are empowered to enforce the Act's prohibition against unfair, deceptive, or abusive financial practices, just like the Consumer Financial Protection Bureau itself. ${ }^{81}$ This provision also expanded the power of the states beyond their own UDAP statutes. For instance, in New York, the state law prohibits only "deceptive" and not "unfair" practices. ${ }^{82}$ No state currently has the authority to police "abusive" financial prac-

\footnotetext{
${ }^{79}$ For an extensive discussion of the general implications of state enforcement of federal law in all sectors, not just consumer protection, see Margaret H. Lemos, State Enforcement of Federal Law, 86 N.Y.U. L. Rev. 698 (2011).

${ }^{80}$ See Amy Widman \& Prentiss Cox, State Attorneys General's Use of Concurrent Public Enforcement Authority in Federal Consumer Protection Laws, 33 Cardozo L. Rev. 53, 66 (2011).

8112 U.S.C. $\S 5552(a)(1)$. A few states had already taken advantage of this new authority as of 2014. See Alan S. Kaplinsky, State Attorneys General File Lawsuits Using Dodd-Frank Authority, 68 Consumer Fin. L.Q. ReP. 199 (2014).

${ }^{82}$ N.Y. Gen. Bus. Law $\$ 349$.
} 
tices under their state UDAP laws ${ }^{83}$ so the authority to enforce the CFPA could be quite meaningful.

Most of the federal laws providing for concurrent state enforcement have certain safeguards to assure that the state enforcers are "on the same page" as the federal government. For example, in the provision for state enforcement of the CFPA, in cases against a national bank or federal savings association, states are empowered to enforce only specific regulations promulgated by the CFPB, but not the general statutory prohibitions. ${ }^{84}$ Other provisions of the federal law require prior notice of a state suit to the relevant federal agency, and provide for the federal agency to intervene in the state suit, or to appeal the outcome ${ }^{85}$ Suits under this provision must be filed "in any district court of the United States in that State or in State court that is located in that State." 86 When states [or individuals] are suing directly under a federal statute, such as is the case in antitrust enforcement, then a federal court, and ultimately the U.S. Supreme Court, can rule on whether or not the plaintiff's legal theory is actually in keeping with the underlying statute. ${ }^{87}$ Thus, a direct right of state enforcement of a federal law can usually provide some level of federal control over the state's enforcement activities.

Yet because the state UDAP statutes were enacted as independent state statutes, federal control and state cooperation is built more on informal means than on statutory safeguards or federal court review. ${ }^{88}$ While Congress could in theory add a state enforcement provision to the FTC Act itself, and also provide direct oversight over state enforcement, that outcome seems unlikely at this point in time. With state UDAP statutes already in place, it is doubtful that any state attorneys general would take advantage of a direct right to enforce the FTC Act. Nonetheless, the current paradigm still provides the essential benefits of extending FTC-style consumer protection enforcement to the states.

\footnotetext{
${ }^{83}$ The term "abusive" financial practice is a new statutory term not found in either the FTC Act or in the state UDAP statutes. Thus, in the absence of this provision of the CFPA, the states would not have the authority to police such practices without amending their own UDAP statutes.

8412 U.S.C. $\$ 5552(\mathrm{a})(2)$. Under this provision, the state AG could not sue a national bank for a practice that the state considered deceptive, unfair or abusive, if that practice has not been specifically prohibited in a regulation promulgated by the CFPB.

8512 U.S.C. $\S 5552$ (b).

8612 U.S.C. $\$ 5552(\mathrm{a})(1)$.

${ }^{87}$ See, e.g., Arizona v. Maricopa Cty. Med. Soc'y, 457 U.S. 332 (1982) (Supreme Court review of state enforcement of Sherman Act).

${ }^{88}$ There is also the embedded provision in most of the state UDAPs that the interpretation of these statutes is to be guided by the jurisprudence of the Federal Trade Commission. See supra note 34 .
} 
Regardless of whether state enforcement of federal consumer protection laws is done directly under a statutory provision or indirectly by enacting state laws based on a federal model, the benefits of state enforcement outweigh the harms. The benefits include spreading the consumer protection mission out to the states to increase efficiency and to deal more effectively with local issues; avoiding inaction due to agency capture since state attorneys general are less likely to be subject to capture than some federal agencies; and developing innovative consumer protection theories since these are more likely to come from the entrepreneurial environment of the state attorneys general offices ${ }^{89}$ The downsides to state enforcement include possible over-enforcement in situations where that might hinder the free flow of truthful commercial information; inadequate guidance to businesses, which may be faced with a patchwork of conflicting laws or conflicting interpretations of the law; and less likelihood of industry self-regulation due to the litigious tendencies of some state AGs. Issues relating to the use of private counsel for state enforcement, expansive imposition of civil penalties in some cases, as well as the occasional disbursement of these funds to allegedly inappropriate recipients have also been raised. ${ }^{90}$ On balance, however, the advantages of state enforcement prevail over the disadvantages in the area of consumer protection.

First, in line with the initial vision of the FTC, state UDAPs spread the mission of consumer protection across the states, so as to make use of more resources for the common good. The resources include not only the staff and budgets available to the state AGs, but also the intelligence the states have with regard to issues that are more regional and local than what the FTC normally monitors.

Second, as seen in the prior discussion of the occasional tensions between state and FTC enforcement over the years, state enforcement can be a check on "agency capture" by the industry or industries the federal agency is charged with regulating. For instance, although Congress gave the Federal Reserve Board the authority to bar unfair mortgage practices in 1994, the agency did not use that power until 2008, well after the subprime mortgage crisis was in full swing. ${ }^{91}$ One likely explanation for this failure to act sooner is agency capture. Likewise, the Office of the Comptroller of the Currency in

\footnotetext{
${ }^{89}$ For a discussion of similar benefits flowing from the state enforcement of antitrust laws, see Stephen Calkins, Perspectives on State and Federal Antitrust Enforcement, 53 Duke L.J. 673, 675 (2003) (listing "familiarity with local and regional markets, closeness to state and local institutions, and ability and experience in compensating individuals" as the main comparative advantages of state enforcement of antitrust laws).

${ }^{90}$ See Silverman \& Wilson, supra note 47.

${ }^{91}$ Jeff Sovern, The Fed's Failure to Act and the Proposed CFPA, Consumer L. \& Pol'y (Aug. 1, 2009), pubcit.typepad.com/clpblog/2009/08/the-feds-failure-to-act-and-the-proposedcfpa.html.
} 
the same period not only did not try to regulate predatory lending, but also acted vigorously to preempt state anti-predatory lending laws. ${ }^{92}$

When such "capture" results in a lack of enforcement by the federal agencies, the states, either under a concurrent enforcement provision or under an equivalent state law, can fill the gap. ${ }^{93}$ State AGs are less likely to be subject to industry capture than federal agency employees because the vast majority, 43 out of 50, are popularly elected and so must win the support of a broad cross-section of voters, as contrasted with federal employees who deal with the same industry players over long periods of time. ${ }^{94}$ Also, it is less likely that a national industry would be willing or able to attempt to "capture" 50 state AGs, as opposed to dealing with one federal agency.

Third, state AGs, being largely independently elected, may want to make their "mark" on a popular area like consumer protection by developing innovative uses of pre-existing laws. States have often been viewed as "laboratories" that can test out new legal approaches which are later adopted by the federal government. As Justice Brandeis noted, "It is one of the happy incidents of the federal system that a single courageous State may, if its citizens choose, serve as a laboratory; and try novel social and economic experiments without risk to the rest of the country." ${ }^{95}$ For example, before the FTC adopted a rule virtually abolishing the holder in due course doctrine from consumer credit transactions, some 40 states had enacted their own legislation on the subject. ${ }^{96}$ More recently, as discussed earlier, in Massachusetts, when the federal government was slow to respond to the subprime mortgage foreclosure crisis, the state AG used an innovative legal theory that lending to residential mortgage borrowers who were very unlikely to be able to repay their loans was an unfair or deceptive practice in violation of the state UDAP statute..$^{97}$ This prohibition on lending to borrowers without the ability to repay was later incorporated into the federal statute. ${ }^{98}$

\footnotetext{
${ }^{22}$ See Christopher L. Peterson, Federalism and Predatory Lending: Unmasking the Deregulatory Agenda, 78 Temple L. Rev. 1, 70-71 (2005).

${ }^{93}$ See David Freeman Engstrom, Private Enforcement's Pathways: Lessons from Qui Tam Litigation, 114 Colum. L. Rev. 1913, 1925 (2014); Totten, supra note 71, at 1658; Amy Widman, Advancing Federalism Concerns in Administrative Law Through a Revitalization of State Enforcement Powers: A Case Study of the Consumer Protect Safety and Improvement Act of 2008, 29 Yale L. \& Pol'y Rev. 165, 175-79 (2010). But see Widman \& Cox, supra note 80, which summarizes a study of state enforcement of federal consumer protection laws that provide for concurrent state enforcement and concludes that they have not thus far been much used outside of the telemarketing area.

${ }^{94}$ Provost, supra note 52, at 37.

${ }^{95}$ New State Ice Co. v. Liebmann, 285 U.S. 262, 311 (1932) (Brandeis, J., dissenting).

${ }^{96}$ Preservation of Consumers' Claims and Defenses, Statement of Basis and Purpose, 40 Fed. Reg. 53,506, 53,508 (Nov. 18, 1975).

${ }^{97}$ Commonwealth v. Fremont Inv. \& Loan, 452 Mass. 733, 897 N.E.2d 548 (2008).

9815 U.S.C. $\S 1639 \mathrm{c}(\mathrm{a})$.
} 
There are also disadvantages to state enforcement in the consumer protection realm. Yet these factors may not be as troublesome as they may seem and are outweighed by the advantages of state enforcement. Critics often cite ambiguity in predictability and lack of guidance to businesses as particular disadvantages. But many states have the authority to issue regulations under their state UDAP laws, for the very reason that specific rules may be beneficial to the entities seeking to comply with the overall statutory directive. ${ }^{99}$ Under most state UDAP laws, state enforcement entities are told they are to be "guided" by FTC policy and practice, which includes a repository of regulations, guides, and case law. ${ }^{100}$ And yet there must be some room for development of new examples of prohibited practices under the state UDAPs or else the law will always be one step behind those unscrupulous merchants who would seek to find new ways to deceive or unfairly treat consumers.

In addition, some may question whether industry self-regulation can flourish under state UDAP enforcement regimes to the same extent as it has under the watch of the federal agencies. The FTC has historically been quite willing to encourage industry self-regulation in appropriate situations. For instance, in the realm of protection of consumer's online privacy, where the "unfairness" of certain online tracking may not yet be firmly delineated, the FTC has called for the industry to voluntarily adopt certain practices that will inform consumers of online tracking and allow them to opt out. ${ }^{101}$ On the other hand, an individual state existing in an interstate economy probably would not be in a position to promote self-regulation for an entire national industry.

Yet enforcement litigation by government entities does not necessarily doom efforts toward industry self-regulation. Concurrent with the FTC's support for self-regulation of online consumer privacy, the FTC has not hesitated to sue when individual companies deceptively promoted privacy policies they did not honor. ${ }^{102}$ States, while perhaps not well-positioned to promote national industry efforts, can work with local bodies like the Better Business Bureau while also suing bad actors when necessary. Indeed, industry self-regulation is only effective if the relevant enforcement agencies can litigate cases not covered by self-regulation, or cases where an individual company has violated its own industry's self-regulation.

\footnotetext{
${ }^{99}$ See supra text accompanying note 26.

${ }^{100}$ See supra text accompanying note 34 .

${ }^{101}$ Fed. Trade Comm'n, Staff Report, Self-Regulatory Principles for Online BehavIORAL ADVERTISING (2009), www.ftc.gov/sites/default/files/documents/reports/federal-trade-com mission-staff-report-self-regulatory-principles-online-behavioral-advertising/p085400behavadre port.pdf.

102 See, e.g., Decision and Order, Google Inc., FTC Docket No. C-4336 (Oct. 13, 2011) (consent order), www.ftc.gov/sites/default/files/documents/cases/2011/10/111024googlebuzzdo.pdf; Decision and Order, Facebook, Inc., FTC Docket No. C-4365 (July 27, 2012) (consent order), www.ftc.gov/sites/default/files/documents/cases/2012/08/120810facebookdo.pdf.
} 
Potential abuses, such as excessive judgments, civil penalties, or private attorneys' fees, can be controlled in ways that would not undermine the basic mission of the state UDAP laws. State courts can rein in state attorneys general who seek or obtain penalties that go beyond their statutory mandate. State legislatures could impose stricter rules about transparency and accountability in the state/private counsel relationship in those rare cases where private counsel is used to enforce the state UDAP laws. If there is a problem with excessive civil penalties and/or the uses of such revenues, state legislatures could also place reasonable limits on fines and how they can be used.

In sum, state enforcement of UDAP statutes or "little FTC Acts" has evolved over the years. The states have at times been more aggressive than their "parent" federal agency, but most of the time have acted in full cooperation with the FTC as well as with the newer CFPB. States have also developed more efficient ways to enforce their own consumer protection statutes, such as by engaging in multistate litigation and drawing on the resources of private counsel to represent the state. These developments, while perhaps not completely foreseen at the time the UDAP statutes were first enacted, have advantages in terms of more complete protection for consumers in the marketplace, advantages which exceed the behavioral adjustments that must be made from time to time by businesses.

The supplemental enforcement efforts by the state attorneys general, beneficial as they are, are not sufficient to uphold the goals of the consumer protection statutes. State attorney general offices are by nature limited in their resources. They do not and cannot provide access to justice for all consumers who need it. Private plaintiffs can act as an extension of state enforcement, in the role of "private attorneys general," and can also achieve individual compensation for consumer injuries in meritorious cases that for whatever reason are not addressed directly by the state agency. Thus, in addition to federal and state enforcement, the third prong of consumer protection, the private right of action, is also critical.

\section{PRIVATE ENFORCEMENT}

\section{A. Public Benefits from Private Enforcement}

Private enforcement of the state UDAP laws is critical to supplement the enforcement activities of the FTC and the states. All states currently feature such a private right of action in their state UDAP statutes. ${ }^{103}$ By enlisting the help of a potentially large cohort of consumer victims or "private attorneys general" empowered to bring their own cases under the state laws, the statu-

${ }^{103}$ See Pridgen \& Alderman, supra note 3, § 6:2. 
tory scheme can not only achieve justice for individual consumers but can also act to deter unfair or deceptive practices in a way that protects the public as a whole. ${ }^{104}$

Early on in the history of the state UDAP laws, state attorneys general and others called for private enforcement because the federal and state governments alone did not have the necessary resources to handle all the consumer issues that were vexing the public. It was also recognized at this time that the private right of action had a public benefit. The Governor of New York in 1980 made the following statement in support of a bill that added a private right of action to the New York consumer protection statute: "This bill, by authorizing private actions, providing for a minimum damage recovery and permitting attorneys' fees will encourage private enforcement of these consumer protection statutes, add a strong deterrent against deceptive business practices and supplement the activities of the Attorney General in the prosecution of consumer fraud complaints." 105

An influential article on state UDAPs published in this formative period also took the position that the expansion of private enforcement under state UDAP laws was the best way to eliminate the gap between government enforcement and the injuries suffered by aggrieved consumers. These authors noted that:

By allowing consumers to enforce FTC jurisprudence, the states have opted, in part, for a private market solution in lieu of government regulation. Clearly, no level of FTC funding could ever approximate the collective enforcement energies of consumers using UDAP statutes. Effective private enforcement thus offers the best deterrent against wrongdoing in the marketplace. ${ }^{106}$

Indeed, the use of private enforcement mechanisms as an extension of administrative agency regulation is a hallmark of the American regulatory system that is by no means unique to the FTC and its complementary state consumer protection acts. ${ }^{107}$ Private rights of action to enforce federal laws can be found in the areas of environmental protection and antitrust, among others. The majority of federal environmental protection statutes have provi-

\footnotetext{
${ }^{104}$ See supra Part II.

${ }^{105}$ Governor's Memorandum on Approval of chs. 345 \& 3461980 N.Y. Laws (June 19, 1980), quoted in Joseph Thomas Moldovan, Note, New York Creates a Private Right of Action to Combat Consumer Fraud: Caveat Venditor, 48 BrookLyn L. Rev. 509, 518 n.29 (1982); cf. Slaney v. Westwood Auto, Inc., 366 Mass. 688, 699, 322 N.E.2d 768, 776-77 (1975) (discussing the need for enabling legislation to make private remedies effective).

${ }^{106}$ Leaffer \& Lipson, supra note 33, at 555.

${ }^{107}$ See J. Maria Glover, The Structural Role of Private Enforcement Mechanisms in Public Law, 53 WM. \& MARY L. Rev. 1137 (2012).
} 
sions for "citizen suits" to supplement government enforcement. ${ }^{108}$ The federal antitrust laws have provided for private enforcement, with treble damages and attorneys' fees, since the 1914 Clayton Act. ${ }^{109}$ Another type of private enforcement can be found in the "qui tam" provisions of the federal False Claims Act. ${ }^{110}$ This law allows private "whistleblowers" to sue on behalf of the United States for fraud connected to federal programs and to earn a portion of the federal money returned pursuant to the suit. ${ }^{111}$

True to the concept of a "private attorney general," these private enforcement mechanisms have similar benefits to those claimed for state enforcement as discussed in the preceding section, i.e., supplementation of government enforcement that is constrained by budget shortfalls, spreading enforcement of meritorious laws across a wider spectrum of beneficiaries, filling the gaps created by captured or otherwise lethargic government agencies, and in an entrepreneurial spirit, pushing the frontiers of legal theories under the relevant laws. On the one hand, private suits can have the indirect effect of promoting the public interest by deterring unfair or deceptive practices. But on the other hand, they could also have the effect of a causing a drift in the precedents away from the originally intended legislative purposes. By their very nature, private suits do not represent a coherent legal effort, but instead reflect the individual situations of the litigants. As in common law development in other areas, the courts of each state may have their own views and philosophies as they review the cases. Thus, the state UDAP court decisions in private suits may not always adhere to what the FTC itself would have done in a similar situation. ${ }^{12}$ Appellate court reviews and limited state legislative tweaks can provide a useful discipline on this potentially unwanted side effect, however, without the need to completely eliminate the private enforcement aspect of state consumer protection laws.

\footnotetext{
108 See, for example, the private citizen action provisions of the Clean Air Act, 42 U.S.C. $\$ 7604$, the Clean Water Act, 33 U.S.C. $\$ 1365$, and the Resource Conservation and Recovery Act, 42 U.S.C. $§$ 6972. See generally Barton H. Thompson, Jr., The Continuing Innovation of Citizen Enforcement, 2000 U. ILl. L. Rev. 185 (discussing how nonprofit organizations and individual citizens may play important roles in uncovering and prosecuting illegal environmental actions).

10915 U.S.C. $\$ 15$. It has been asserted that $95 \%$ of all antitrust cases are brought by private plaintiffs. Herbert Hovenkamp, Federal Antitrust Policy: The Law of Competition and Its Practice $\S 16.1$ (4th ed. 2011); see also Daniel A. Crane, Optimizing Private Antitrust Enforcement, 63 Vand. L. Rev. 675 (2010).

11031 U.S.C. $\S \S 3729-3733$. See generally Engstrom, supra note 93, at 1914-15.

${ }^{111} I d$.

112 See Searle Civil Justice Inst., State Consumer Protection Acts: An Empirical Investigation of Private Litigation 6 (2009).
} 


\section{B. Private Benefits for Consumers Through Private Enforcement}

Prior to the passage of the state UDAP laws, consumers who were wronged by merchants in the marketplace were mostly limited to common law causes of action, such as the tort of fraud or misrepresentation, breach of warranty, or unconscionability. ${ }^{113}$ Not only did consumers face high burdens of proof for these common law causes of action, but also their costs of litigation would usually be higher than their relatively small economic losses, thus undermining the ability for consumers to gain access to the courts. ${ }^{114}$ Thus, the state UDAP statutes were passed to address these harms to consumers by lowering the burden of proof and providing consumers a right of action that also normally includes attorneys' fees for the prevailing consumer plaintiff as well as, in some cases, statutory damages. ${ }^{115}$

The private right of action and the state powers of enforcement are truly complementary, not exclusive. There have been many instances of beneficial cases brought by a private plaintiff that might not have been brought or might not have succeeded in a state enforcement action, and vice versa. For instance, in the area of "bait and switch" advertising, prosecutions by the state have been elusive, whereas there has been some success with a private action approach. Bait and switch advertising involves the promotion of products or services at a relatively low price, when the seller has no intention of selling the item advertised but instead is using it as "bait" or a ploy to get consumers in the door in order to "switch" them to a higher priced item. ${ }^{116}$ In a case brought by the Wisconsin Attorney General in the late 1980s, the state relied on inferences from various aspects of the marketing scheme, such as the low number of advertised items ordered or sold, the lack of commissions offered on the advertised item because they were priced under cost, and no credit cards accepted on the advertised items, to prove their case that the advertiser had no intent to sell the advertised items. ${ }^{117}$ The defendant appliance store moved to dismiss for failure to state a claim, and ultimately the Wisconsin

113 See supra discussion Part I.B at text accompanying notes 34-39. Note that this discussion is limited to the consumer's loss in economic value of a product or service due to a merchant's unfair or deceptive practice. Defective products that cause physical injury or death come under an entirely different legal regime, i.e., products liability that does not cover the type of loss addressed by the state UDAP statutes.

114 See supra discussion at text accompanying notes 39-42.

115 See Pridgen, Wrecking Ball, supra note 40, at 288-89.

116 The FTC defines bait advertising as "an alluring but insincere offer to sell a product or service which the advertiser in truth does not intend or want to sell. Its purpose is to switch consumers from buying the advertised merchandise, in order to sell something else, usually at a higher price or on a basis more advantageous to the advertiser." Fed. Trade Comm'n, Guides Against Bait Advertising, 16 C.F.R. $§ 238.0$.

117 State v. Am. TV \& Appliance of Madison, Inc., 146 Wis. 2d 292, 430 N.W.2d 709 (1988). 
Supreme Court agreed with the defendant that the attorney general's case was insufficient. ${ }^{118}$

By contrast, private plaintiffs in a case out of Hawaii alleged a bait and switch ad campaign by a car dealer, in which the consumers suffered some damages from a wasted trip but did not in fact buy anything. ${ }^{119}$ The Hawaii Supreme Court declared that "there is no discernible reason why a consumer should be required to actually purchase any goods or services as a precondition to bringing an action ... for damages that result from injuries caused by false or misleading advertisements." 120 Thus the consumers were able to recover their damages, and the case may have served to deter other dealers contemplating the use of bait and switch advertising, in a situation where it is unclear whether the state attorney general would have pursued this case or been successful if it had pursued it.

In a New Jersey case from 2013, an individual plaintiff who was a property owner brought a Consumer Fraud Act case against a mortgage foreclosure rescue scammer and ultimately won treble damages and got the title to the property restored. ${ }^{121}$ In this case, the defendant had tricked the plaintiff into surrendering title to the property without providing anything of value in return, resulting in the plaintiff's loss of equity in the home. The New Jersey Supreme Court noted that treble damages were authorized by the statute as a deterrent and were not precluded by the injunctive relief awarded. ${ }^{122}$ In this case, the private plaintiff got an individualized remedy and also acted as a private attorney general in a case where, although there were a significant number of amicus briefs filed by public interest groups, the state attorney general apparently chose not to act. ${ }^{123}$

Other types of consumer cases have proven more amenable to action by public enforcers than private suits. One example of this is the marketing of various magazine publications through the use of sweepstakes promotions. In a California state UDAP case, the individual plaintiff, Michael Freeman, failed to convince the court that a sweepstakes letter addressed to him from Time, Inc. was deceptive. ${ }^{124}$ In the letter, the marketer had declared several times in bold and all-capitalized letters that "MICHAEL FREEMAN HAS WON $\$ \mathbf{1 , 6 6 6 , 6 7 5 . 0 0 "}$ " or words to that effect, while at the same time the qual-

\footnotetext{
${ }^{118} I d$.

119 Zanakis-Pico v. Cutter Dodge, Inc., 98 Haw. 309, 47 P.3d 1222 (2002).

${ }^{120}$ Id. at 98 Haw. $318-19,47$ P.3d at 1231-32.

121 D'Agostino v. Maldonado, 216 N.J. 168, 78 A.3d 527 (2013).

${ }^{122}$ Id. 216 N.J. at $197-99,78$ A.3d at 545-46.

${ }^{123}$ Amicus briefs were submitted in the case by Legal Services of New Jersey, the Consumers League of New Jersey, and the Seton Hall University School of Law Center for Social Justice.

${ }^{124}$ Freeman v. Time, Inc., 68 F.3d 285 (9th Cir. 1995).
} 
ifying phrase "if you return the grand prize winner number" was not so emphasized. ${ }^{125}$ The court applied the FTC's deception policy statement and concluded that a reasonable consumer would have read the letter as a whole and would not be deceived into thinking he had already won the prize. ${ }^{126}$

By contrast, a multistate attorney general group convinced a different sweepstakes promoter, Publisher's Clearing House, to enter into a detailed settlement that eliminated many of the deceptive sweepstakes promotion practices that had preyed on an unsuspecting elderly population. ${ }^{127}$ This may have been due in part to the threat of the states acting in concert. It may have also been partly due to the AGs greater focus on the use of sweepstakes promotions to sell magazines by implying recipients could improve their chances of winning by subscribing, rather than on false implications that the recipients had already won. Several states also came together to obtain a settlement against American Family Publishers, which also included specific measures to eliminate deceptive practices in sweepstakes promotions. ${ }^{128}$ This may well have been a situation in which the state enforcers were in a better position to regulate this area than individuals.

Private lawsuits to enforce state UDAP statutes have blossomed over the years and provide a much needed pathway to justice for consumers. Private UDAP enforcement provides both public benefits in terms of deterring unfair and deceptive practices and supplementing government enforcement, as well as the private benefit of giving consumers a viable legal remedy for marketplace wrongs by going above and beyond the rather limited recourse consumers had under common law fraud actions. The private right of action for UDAP statutes, however, is currently under attack.

\section{Attacks on Private UDAP Litigation}

Attacks on private UDAP litigation have become particularly harsh in recent years, with some even calling for its elimination, either outright or in effect. For instance, a model act put forth by the American Legislative Exchange Council (ALEC), while purporting to be a reform of the private enforcement provisions of state UDAP statutes, is actually a destructive engine

\footnotetext{
${ }^{125} \mathrm{Id}$. at 287.

${ }^{126}$ Id. at 289-90. The FTC's deception policy can be found at www.ftc.gov/system/files/docu ments/public_statements/410531/831014deceptionstmt.pdf. The FTC policy basically says that a deceptive trade practice consists of a representation, omission, or practice that is likely to mislead a consumer acting reasonably under the circumstances. Id.

${ }^{127}$ Publisher's Clearing House Resolves States' Sweepstakes Solicitation Concerns," ANTITRust \& Trade Reg. Rep. (BNA) No. 67, at 283 (Sept. 1, 1994).

128 See Provost, supra note 52, at 48.
} 
that would in effect eliminate the private right of action. ${ }^{129}$ The main criticisms of private enforcement of state UDAPs are fivefold.

First, critics say that overly vigorous private enforcement can chill commercial speech and have an adverse effect on the marketplace. Second, some say that private enforcement of public law needlessly expands the number and types of cases brought due to the private attorneys' interest in the "gold rush" of attorneys' fees. Third, some have argued that private enforcement is unnecessary due to the availability of state enforcement of the UDAP statutes. Fourth, scholars have claimed that private enforcement of state UDAP statutes has led to the expansion of the law beyond what the FTC, the supposed guiding light, would sanction. Finally, opponents of private UDAP actions say that these laws are improperly being used as a substitute for personal injury or products liability tort cases, resulting in excessive damages and attorneys' fee awards that would not otherwise be available. Each of these five criticisms will be addressed in turn.

Some scholars have asserted that overly vigorous enforcement of the law against deceptive or unfair marketing of consumer products chills commercial communications from advertisers to consumers. These scholars say that this has an adverse effect on the marketplace, which relies on advertising to promote competition and provide product information to consumers. ${ }^{130}$ The breadth and ambiguity of the terms "unfair" and "deceptive," as well as the discretion of the private plaintiffs and their attorneys to choose their cases, appear to be at the heart of this particular objection. This argument proves too much, however. While commercial advertising plays a critical role in the free market economy, the limitations posed by the statutory prohibition of unfair or deceptive practices have not proven to be so deleterious. Admittedly, there are always new frontiers and new developments in the definitions of unfair or deceptive trade practices that may catch some advertisers by surprise, but after many years of private (as well as state and federal) enforcement under this standard, the advertising of products and services in our economy appears to continue apace. Undue suppression of truthful commercial speech is also vigorously policed by the U.S. Supreme Court. ${ }^{131}$

Critics of private enforcement of public law also say that the private bar needlessly expands the number of cases in search of excessive fees and penal-

\footnotetext{
${ }^{129}$ See Pridgen, Wrecking Ball, supra note 40.

${ }^{130}$ Henry N. Butler \& Jason S. Johnston, Reforming State Consumer Protection Liability: An Economic Approach, 2010 Colum. Bus. L. Rev. 1, 35-53 (2010).

${ }^{131}$ See, e.g., 44 Liquormart, Inc. v. Rhode Island, 517 U.S. 484 (1996) (striking down a state ban on price advertising for alcoholic beverages).
} 
ties, resulting in a type of "gold rush" mentality. ${ }^{132}$ In a study of qui tam cases, however, one author found the litigation explosion claim to be untrue. The author concluded that there has been a slow but steady (not explosive) growth in the number of private suits as the law in that particular area matures. ${ }^{133}$ With regard to state consumer protection laws in particular, one article claimed that appellate courts experienced a 43 percent increase in the volume of litigation under these laws in the years 2000-2007. ${ }^{134}$ Whether or not this would be considered an undue increase depends on the point of view being taken. ${ }^{135}$ Some would argue that it simply took a few years for the value of the state UDAP action to consumers to be realized, ${ }^{136}$ which might point to a slow but steady rise in suits rather than any type of litigation flood. It could also be argued that any increase in private UDAP cases simply means that more consumers are obtaining justice under the law and not necessarily that the bulk of the lawsuits were unfounded.

As discussed in the previous section, the state attorneys general are usually authorized to sue for damages or restitution on behalf of consumers, and can also obtain injunctive relief to protect all consumers in their state from future incursions by the same wrongdoer, or by an entire industry. Thus, some have argued that state enforcement of the consumer protection laws is sufficient and would avoid some of the alleged excesses of individual or class actions. ${ }^{137}$ This argument is flawed, however, for a number of reasons. First, state resources, like all government resources, are limited, so that the pool of unredressed consumer injuries is likely to be greater than can be taken care of by the state (or federal) governments. State attorneys general thus have to choose their targets carefully, which could leave some consumers unprotected and some unscrupulous merchants undeterred. This is particularly true for incidents that may only affect one person or a small number of persons and, thus,

\footnotetext{
132 See Joanna M. Shepherd-Bailey, Consumer Protection Acts or Consumer Litigation Acts?: A Historical and Empirical Examination of State CPAs (Dec. 2016), www.atra.org/wp-content/ uploads/2016/12/Shepherd-Bailey-White-Paper-FINAL.pdf.

${ }_{133}$ See Engstrom, supra note 93, at 1951-63.

${ }^{134}$ Butler \& Johnston, supra note 130, at 6.

135 It has been argued that the private and societal incentives for bringing lawsuits diverge because the costs and benefits to the individual and to society diverge. See Steven Shavell, The Fundamental Divergence Between the Private and the Social Motive to Use the Legal System, 26 J. Legal Stud. 575 (1997). Thus, it may be quite difficult to determine whether there is too much or too little litigation in any given area.

136 See Leaffer \& Lipson, supra note 33, at 522; Stewart Macaulay, Bambi Meets Godzilla: Reflections on Contracts Scholarship and Teaching vs. State Unfair and Deceptive Trade Practices and Consumer Protection Statutes, Address Before the Association of American Law Schools (Jan. 9, 1988), reprinted in 26 Hous. L. Rev. 575 (1989).

${ }_{137}$ See Sheila B. Scheuerman, The Consumer Fraud Class Action: Reining in Abuse by Requiring Plaintiffs to Allege Reliance as an Essential Element, 43 Harv. J. ON Legis. 1 (2006).
} 
may not rise to the level of public interest that must be the guiding light of state cases. ${ }^{138}$

Aside from lack of resources, some state AGs may be inefficient, lethargic, understaffed, overly cautious, or held back by political constraints. While most state AGs are elected and, thus, may actually be motivated to pursue high-profile consumer cases in order to win votes, other states either have appointed AGs or function in a political environment where consumer protection cases are not viewed with favor. ${ }^{139}$ For instance, an attorney general in an energy-rich state might not be inclined to sue an energy company even though consumer harm was present. The aggressiveness of state enforcement varies greatly from state to state, and over time as well, as the political climate and views of consumer protection versus business protection may change. This raises the question of whether the legislatures that passed the state UDAPs would have wanted to leave some consumers blocked from the courthouse and their concerns relegated to the era of caveat emptor simply because they happen to live in a state that has a particularly inactive or unsympathetic state attorney general. The private right of action thus acts as a safety net that can potentially protect consumers who do not have the advantage of an attorney general's office with a large consumer protection division and a pro-consumer attorney general.

Some scholars, including a former FTC Commissioner, have asserted that the state UDAP cases, especially the ones brought through private enforcement actions, have gone beyond the original mission of allowing states and individuals to effectively enforce the FTC Act's prohibition against unfair and deceptive trade practices. ${ }^{140}$ As discussed above, the goal of extending the FTC's consumer protection mission to the states was indeed part of the genesis of the state UDAP statutes. ${ }^{141}$ Most of the state laws contain provisions specifying that the state law should be "guided" by FTC jurisprudence in this area. ${ }^{142}$ Since these are state laws, however, and not a situation where the state and private enforcement is granted directly by the federal statute itself, states are free to go beyond what the FTC has done or would do. ${ }^{143}$ There is no legal

\footnotetext{
138 See Prentiss Cox, Goliath Has the Slingshot: Public Benefit and Private Enforcement of Minnesota Consumer Protection Laws, 33 WM. Mitchell. L. Rev. 163 (2006) (arguing that private enforcement of consumer cases that may not rise to the level of public benefit needed for state action is critical to achieve social justice for all consumers).

139 See Provost, supra note 52.

${ }^{140}$ Henry N. Butler \& Joshua D. Wright, Are State Consumer Protection Acts Really LittleFTC Acts?, 63 Fla. L. Rev. 163 (2011). Joshua Wright served as an FTC Commissioner from 2013-2015.

${ }^{141}$ See supra Part I.B.

${ }^{142}$ See supra discussion at text accompanying notes 33-34.

${ }^{143}$ State laws are of course limited by the doctrine of federal preemption, but that doctrine has not been exercised to any great extent by the FTC perhaps because the areas of consumer fraud
} 
obligation for states to strictly follow FTC precedent or policies. And, in fact, the states and private plaintiffs can play a valuable role in extending the applications of the broad ban on deceptive and unfair practices beyond what the federal government might be doing as a check on federal agency capture or bureaucratic paralysis, as discussed in Part II.

Finally, private UDAP enforcement has been criticized due to the perception that plaintiffs are using these rights of action as a substitute for personal injury or products liability lawsuits that would normally be litigated as tort cases. ${ }^{144}$ One example given is a Massachusetts case in which college student fell down some stairs in a bar and died. The parents of the deceased student sued the bar owners for an unfair trade practice since the staircase was defective in violation of multiple provisions of the state building code. This state UDAP claim succeeded even as the concurrent wrongful death claim failed. ${ }^{145}$ Cases against companies advertising "light" cigarettes as well as cases alleging undisclosed side effects of prescriptions drugs are also cited as examples of state UDAP cases that should have been tried as torts. ${ }^{146}$ This concern is over-stated, however, because in many if not most states, a cause of action based on physical rather than economic injury is not covered under the state UDAP statute. ${ }^{147}$ Also, some state statutes limit recovery to injuries to business or property, thus eliminating most tort cases involving physical injury or wrongful death in those states. ${ }^{148}$

The related issues of excessive damages or attorneys' fee awards are not unique to private suits under state consumer protection statutes. These are perennial subjects in any discussion of tort reform and/or class actions in general, and many laws are already in place to deal with such issues. There are also limits on the filing of frivolous lawsuits brought by attorneys for harassment purposes. ${ }^{149}$

\footnotetext{
and unconscionable market practices have traditionally been matters of state law. Also, the FTC itself was a key player in developing the state UDAP law models as independently enacted state statutes. See supra discussion at text accompanying notes 25-26.

144 Am. Tort Reform Found., State Consumer Protection Laws Unhinged (2013), www.consumerlawsunhinged.org/state-consumer-protection-laws-unhinged/.

${ }^{145}$ Klairmont v. Gainsboro Rest., Inc., 465 Mass. 165, 987 N.E.2d 1247 (2013).

${ }^{146}$ See Victor E. Schwartz \& Cary Silverman, Common-Sense Construction of Consumer Protection Acts, 54 Kan. L. Rev. 1, 41-46, 48-49 (2005).

147 See Pridgen \& Alderman, supra note 3, § 4:13.

148 See, e.g., Ass'n of Wash. Pub. Hosp. Dists. v. Philip Morris, Inc., 241 F.3d 696 (9th Cir. 2001) (applying Washington law); Blowers v. Eli Lilly \& Co., 100 F. Supp. $2 d 1265$ (D. Haw. 2000) (applying Hawaii law).

${ }^{149}$ See FED. R. CIV. P. 11 (providing for sanctions against attorneys who file frivolous
} lawsuits). 


\section{Limited Reforms for Private UDAP Litigation}

The arguments for the elimination of private UDAP lawsuits, as discussed above, are readily rebutted. Furthermore, each of the criticisms of private UDAP enforcement can and are being addressed by the states through limited reforms, thus obviating the need for wholesale elimination of the private right of action. ${ }^{150}$

State courts exercising the power of appellate review can limit the extent to which either private or state UDAP suits are allowed to extend beyond the confines of their own state law, which are in fact modeled on the FTC Act and most of which explicitly state that interpretation of the state law is to be guided by FTC jurisprudence. ${ }^{151}$ An alternative way of dealing with any perceived straying from the path of FTC consumer policy would be for the state legislatures to amend their statutes to incorporate FTC consumer policies on deception or unfairness. ${ }^{152}$

Over the years since their initial passage, some state UDAP statutes have been expanded to include business-to-business cases. The state consumer protection statutes, with their lower burdens of proof and added remedies are often attractive as an alternative for businesses that may want to litigate unfair or deceptive trade practice claims against other businesses. ${ }^{153}$ Fifteen states extend the coverage of their state UDAP statutes to disputes between businesses, and do not restrict suits to consumer transactions. ${ }^{154}$ This expansion may have led to the increase in UDAP suits nationwide, and at least one study found that the damage awards in business UDAP litigation was significantly higher than damages awarded in cases brought by individuals. ${ }^{155}$ One way to

${ }^{150}$ See Pridgen, Wrecking Ball, supra note 40, in which I argue that the American Legislative Exchange Council (ALEC) model law on private enforcement of state consumer protection laws, while purporting to be a reform of state UDAPs, is actually a destructive engine that would in effect eliminate the private right of action. In this Symposium article, I acknowledge that there may be some limited reforms in this area that would not have the effect of destroying the benefits of the state UDAP private right of action.

${ }^{151}$ See J.R. Franke \& D.A. Ballam, New Applications of Consumer Protection Law: Judicial Activism or Legislative Directive?, 32 Santa Clara L. Rev. 347 (1992). The authors looked at seven states that were among the most active in applying their state consumer protection laws to "fringe" areas and concluded that the cases did not extend the law of unfair and deceptive practices beyond the legislative intent.

${ }^{152}$ See Matthew W. Sawchak \& Kip D. Nelson, Defining Unfairness in "Unfair Trade Practices," 90 N.C. L. REv. 2033 (2012) (advocating that the state legislature should incorporate the language of the current FTC unfairness policy into the state law).

${ }^{153}$ For instance, in a Minnesota case, a commercial farmer was able to use the state consumer protection statute to secure a $\$ 3.7$ million verdict plus attorneys' fees and costs from a silo manufacturer on the basis of misleading advertising. Kronebusch v. MVBA Harvestore Sys., 488 N.W.2d 490 (Minn. Ct. App. 1992).

${ }^{154}$ See Pridgen \& Alderman, supra note 3, § 4:3 \& app. 4A.

155 Nancy Friedman Atlas, Scott J. Atlas \& Raymond T. Nimmer, DPTA in the Courts: Two Empirical Studies and a Proposal for Change, 21 ST. MARY's L.J. 609, 657 (1990). After this 
rein in state UDAP laws is to limit them to consumer cases and eliminate their application to business disputes, with the possible exception of disputes where the plaintiff is a small business owner suing a larger business.

But as noted above, the state UDAP laws originated in a consumer protection context, with a goal of protecting consumers who would otherwise be inadequately protected under then-existing law. Most of the UDAP statutes are limited to consumer plaintiffs in the context of consumer transactions. ${ }^{156}$ Some states limit their coverage to "trade or commerce," which is defined as goods or services provided for "personal, family, or household purposes."157 The theory behind the original limitation of state UDAP statutes to disputes between consumers and businesses was that consumers need this additional legal boost of enhanced remedial provisions because consumers are not on the same footing as the businesses with whom they deal and because their individual losses might be too small to pay for competent legal representation. Businesses dealing with other businesses were presumed to have equal resources to hire attorneys and negotiate at arm's length for favorable contract terms. While some states have extended coverage under their state UDAP statutes to business plaintiffs, especially small business plaintiffs, ${ }^{158}$ the wellfounded general rule remains that these special laws are for the benefit of consumers.

Another potential reform that could limit the overreach of private enforcement would be to add a "public interest" requirement to both private and public suits. A "public interest" requirement has been imposed by courts construing their state consumer protection laws in Colorado, ${ }^{159}$ Georgia, ${ }^{160} \mathrm{Ne}-$

study, the Texas legislature amended the law to limit the use of the state UDAP statute for certain large transactions. Tex. Bus. \& Com. Code Ann. § 17.49(f)-(g).

156 See Pridgen \& Alderman, supra note 3, at app. 4A.

${ }_{157}$ Мich. Comp. Laws. AnN. $\S \S 445.903(1)$, 445.902(g). The Sixth Circuit Court of Appeals applied this language to exclude a state UDAP cause of action by disgruntled law school graduates who had alleged that their school had enticed them to matriculate with inflated post-graduation employment statistics. MacDonald v. Thomas M. Cooley Law Sch., 724 F.3d 654 (6th Cir. 2013).

158 See, e.g., Ly v. Nystrom, 615 N.W.2d 302 (Minn. 2000) (Minnesota Supreme Court viewed individual purchaser of a small business as a "consumer" for purposes of applying the state Consumer Fraud Act, although they did not conclude that he was entitled to attorneys' fees under the state's "Private Attorney General" statute because it was an isolated transaction).

${ }^{159}$ Hall v. Walter, 969 P.2d 224 (Colo. 1998).

${ }^{160}$ Zeeman v. Black, 156 Ga. App. 82, 273 S.E.2d 910 (1980). 
braska, ${ }^{161}$ New York, ${ }^{162}$ South Carolina, ${ }^{163}$ and Washington. ${ }^{164}$ In West Virginia, the statute itself specifies that it prohibits only acts or practices injurious to the public interest. ${ }^{165}$ Some consumer advocates have argued against the public interest requirement for private suits on the basis that only public agencies should be so limited. ${ }^{166}$ On the other hand, if private plaintiffs are viewed as "private attorneys general," acting as de facto public enforcers, then some public interest requirement may be relevant.

Another reform that could limit private enforcement to cases where the challenged practice has actually caused harm to consumers is the "ascertainable loss" requirement. Thirty-four state consumer protection statutes require that a private plaintiff prove that he or she has suffered some damage, injury, or "ascertainable loss" as a result of the unfair or deceptive trade practice being challenged in a private suit. ${ }^{167}$ This concept is not the same as out-ofpocket loss or reasonable reliance, but it does require that private plaintiffs show some type of loss of the benefit of the bargain in order to go to court under the state UDAP law with its attendant litigation benefits. For example, a consumer can suffer an "ascertainable loss" based on the purchase of a product that does not have the features that were advertised even though there was no resulting loss in fair market value, ${ }^{168}$ or based on hard to quantify losses, such as a loss of credit availability resulting from the card issuer's erroneous collection action, even though the customer could not prove the actual amount of damages associated with the loss of credit. ${ }^{169}$ This requirement provides an adequate gateway or filter to assure that the private plaintiff is an actual victim of an unfair or deceptive trade practice, without the need to return to any type of out of pocket loss or reasonable reliance requirement, as advocated by some. ${ }^{170}$ Requiring consumers to show out of pocket loss, on the other hand,

${ }^{161}$ Nelson v. Lusterstone Surfacing Co., 258 Neb. 678, 605 N.W.2d 136 (2000).

162 Oswego Laborers' Local 214 Pension Fund v. Marine Midland Bank, N.A., 85 N.Y.2d 20, 647 N.E.2d 741 (1995).

163 Noack Enters., Inc. v. Country Creamer Interiors of Hilton Head Island, Inc., 290 S.C. 475, 351 S.E.2d 347 (Ct. App. 1986).

${ }^{164}$ Hangman Ridge Training Stables, Inc. v. Safeco Title Ins. Co., 105 Wash. 2d 778, 719 P.2d 531 (1986) (en banc).

165 W. VA. CODE $\S 46 \mathrm{~A}-6-101$.

166 See, e.g., Mark E. Budnitz, The Federalization and Privatization of Public Consumer Protection Law in the United States: Their Effect on Litigation and Enforcement, 24 GA. ST. U. L. REv. 663, 679 (2008) (arguing that imposing a "public interest" requirement for private suits will deny relief to many consumers and is a difficult standard for courts to apply).

167 See Pridgen \& Alderman, supra note 3, at app. 5A.

${ }^{168}$ Hinchliffe v. Am. Motors Corp., 184 Conn. 607, 440 A.2d 810 (1981).

${ }^{169}$ Discover Bank v. Morgan, 363 S.W.3d 479 (Tenn. 2012).

170 See Am. Legis. Exch. Council, Model Act on Private Enforcement of Consumer Protection Statutes Act, ALEC.orG, www.alec.org/model-policy/private-enforcement-of-consumer-protection-statutes-act/. (The ALEC Model Act defines Ascertainable loss" as limited to losses of money or property, i.e., "out of pocket" loss, which is narrower than the prevailing law.) 
would eliminate suits where the harm is difficult to quantify but still real, as in cases involving harm to one's credit rating, or the waste of time involved in bait and switch advertising.

Reasonable reliance is based on traditional tort requirements for a fraud cause of action, whereas UDAP laws were meant to eliminate such obstacles for consumer victims. ${ }^{171}$ Reasonable reliance is an unnecessary obstacle that would mean consumers would have to show individually that they not only relied on the questioned practice or representation, but also that they were "reasonable" in doing so, thus diminishing the mantle of protection for the average consumer. An "ascertainable loss" requirement that is broadly defined should be sufficient to protect businesses from suits against harmless practices.

As to the uncertainty for businesses of a law prohibiting "unfair and deceptive" trade practices, one approach would be to limit private suits to enumerated violations. ${ }^{172}$ This type of limitation, while arguably improving the specific business guidance contained in the statute, has the unfortunate effect of shielding defendants from liability for unfair or deceptive practices that might not have been foreseen at the time of the legislation. Limiting suits in such a way could undermine the ability of the consumer protection laws to keep up with current changes in market practices. A better approach would be to have a state law that lists specific unfair or deceptive practices, has a "catch-all" provision covering other yet unknown unfair or deceptive practices, and also allows merchants to defend themselves by proving that the particular lawsuit at issue would not be in the public interest, perhaps because the merchant could not have reasonably avoided the alleged violation. ${ }^{173}$

As to the flood of litigation claim, there are currently many legal restrictions in play that have tended to reduce private consumer protection suits. For instance, consumer class actions have been hammered by scholarly and political criticism, resulting in various types of legislative reforms. ${ }^{174}$ Also, the widespread use of mandatory arbitration clauses in consumer contracts al-

\footnotetext{
171 "Reasonable reliance" is akin to the "justifiable reliance" requirement for common law fraud, which is a relatively burdensome standard in itself. Prosser \& KeEton, supra note 35, $\S 105$, at 728 . A "reasonable reliance" requirement would also eliminate most UDAP claims based on unfairness, which do not involve any reliance on a particular statement, but rather are addressed to practices which are abusive, such as price gouging, or privacy invasions or personal data breaches.

172 See Or. Rev. Stat. § 646.608(4); Tenn. Code Ann. § 47-18-104.

173 Jeff Sovern, Private Actions Under the Deceptive Trade Practices Acts: Reconsidering the FTC Act as Rule Model, 52 Oніо Sт. L.J. 437, 462-67 (1991).

${ }_{174}$ See, e.g., Class Action Fairness Act of 2005, Pub. L. No. 109-2, which expanded federal jurisdiction over class actions. See 28 U.S.C. § 1332(2) (providing for federal jurisdiction in large class actions with minimal diversity); 28 U.S.C. $\$ 1453$ (making it easier to remove class actions to federal courts); 28 U.S.C. $\$ 1712$ (limiting attorneys' fees in "coupon settlements").
} 
ready keeps many consumer disputes out of court, especially class actions. ${ }^{175}$ Given the legal environment of today, there is no need for the elimination of private UDAP enforcement. Some of the limited reforms discussed above should be more than sufficient to address any concerns about overreaching or inappropriate uses of the state UDAP statutes.

\section{CONCLUSION}

The viable presence of both state and private enforcement of state UDAP laws is needed to achieve the optimum level of consumer protection in this country. The dual enforcement scenario was a critical aspect of the original UDAP statutes based on the model act developed by the FTC and adopted by the states in the 1960s and 70s. These laws were aimed at both extending the influence of the FTC's consumer protection mission to the states, and also enhancing individual recovery for unfair or deceptive trade practices. State enforcers, typically the state attorneys general, have wide-ranging powers under these laws, and they have used them relatively aggressively since the original passage. State AGs can at times push ahead of their federal counterpart agencies due to their position as entrepreneurial elected officials. This can stretch the boundaries of consumer protection in ways that benefit consumers. Indeed, the back and forth rivalry between the state and the federal consumer protectors has actually resulted in a dynamic that fosters both progress and cooperation among governmental entities.

The second half of the dynamic duo, i.e., private enforcement, is just as important as its state government partner. By bringing a variety of individual or class actions against specific unfair or deceptive practices, successful private actions can create a deterrent effect that protects the public as a whole. Private enforcement of small claims under the state UDAP statutes can also help achieve just compensation to individuals harmed by unfair or deceptive trade practices that could not be obtained through common law actions or by the sometimes uneven enforcement by the state AGs. Both state and private enforcement are needed to achieve the goals of the state consumer protection laws. Any uncertainty for businesses or excessive awards for consumers or their attorneys can be addressed through either state appellate court review or limited state legislative reforms. There is no need to disarm the dynamic duo of state and private enforcement.

175 See AT\&T Mobility LLC v. Concepcion, 563 U.S. 333 (2011) (approving the use of mandatory arbitration clauses with class arbitration waivers in consumer contracts); see also Jean R. Sternlight \& Elizabeth J. Jensen, Using Arbitration to Eliminate Consumer Class Actions: Efficient Business Practice or Unconscionable Abuse?, 67 L. \& Contemp. Probs. 75 (2004). 